3. McVey DS, Drolet BS, Ruder MG, Wilson WC, Nayduch D, Pfannenstiel R, et al. Orbiviruses: a North American perspective. Vector Borne Zoonotic Dis. 2015;15:335-8. http://dx.doi.org/10.1089/vbz.2014.1699

4. Pybus MJ, Ravi M, Pollock C. Epizootic hemorrhagic disease in Alberta, Canada. J Wildl Dis. 2014;50:720-2. http://dx.doi.org/ 10.7589/2014-02-024

5 Howerth EW, Stallknecht DE, Kirkland PD. Bluetongue, epizootic hemorrhagic disease, and other orbivirus-related diseases. In: Williams ES, Barker IK, editors. Infectious diseases of wild mammals. Ames (IA): Iowa State University Press; 2001. p. 82-9.

6. Pasick J, Handel K, Zhou EM, Clavijo A, Coates J, Robinson Y, et al. Incursion of epizootic hemorrhagic disease into the Okanagan Valley, British Columbia in 1999. Can Vet J. 2001;42:207-9.

7. Wirth WW, Dyce AL, Peterson BV. An atlas of wing photographs with a summary of the numerical characters of the Nearctic species of Culicoides (Diptera: Ceratopogonidae). Contrib Am Entomol Inst. $1985 ; 22: 1-46$.

8. Stallknecht DE, Allison AB, Park AW, Phillips JE, Goekjian VH, Nettles VF, et al. Apparent increase of reported hemorrhagic disease in the midwestern and northeastern USA. J Wildl Dis. 2015;51:348-61. http://dx.doi.org/10.7589/2013-12-330

9. Pfannenstiel RS, Mullens BA, Ruder MG, Zurek L, Cohnstaedt LW, Nayduch D. Management of North American Culicoides biting midges: current knowledge and research needs. Vector Borne Zoonotic Dis. 2015;15:374-84. http://dx.doi.org/10.1089/ vbz.2014.1705

10. Jewiss-Gaines A, Barelli L, Hunter FF. First records of Culicoides sonorensis (Diptera: Ceratopogonidae), a known vector of bluetongue virus, in southern Ontario. J Med Entomol. 2017; $54: 757-62$.

Address for correspondence: Samantha E. Allen, University of Guelph, 50 Stone Rd E, Guelph, ON N1G 2W1, Canada; email: sallen02@uoguelph.ca

\section{Effects of Political Instability in Venezuela on Malaria Resurgence at Ecuador-Peru Border, 2018}

\author{
Robinson Jaramillo-Ochoa, ${ }^{1}$ Rachel Sippy, ${ }^{1}$ \\ Daniel F. Farrell, ${ }^{1}$ Cinthya Cueva-Aponte, ${ }^{1}$ \\ Efraín Beltrán-Ayala, Jose L. Gonzaga, \\ Tania Ordoñez-León, Fernando A. Quintana, \\ Sadie J. Ryan, Anna M. Stewart-Ibarra
}

Author affiliations: Ministerio de Salud Pública del Ecuador, Machala, Ecuador (R. Jaramillo-Ochoa, J.L. Gonzaga,

T. Ordoñez-León); State University of New York Upstate Medical

${ }^{1}$ These authors contributed equally to this article.
University, Syracuse, New York, USA (R. Sippy, D.F. Farrell, C. Cueva-Aponte, A.M. Stewart-lbarra); University of Florida, Gainesville, Florida, USA (R. Sippy, S.J. Ryan); Universidad Técnica, Machala (E. Beltrán-Ayala); Ministerio de Salud de Peru, Tumbes, Peru (F.A. Quintana)

DOI: https://doi.org/10.3201/eid2504.181355

Mass migration from Venezuela has increased malaria resurgence risk across South America. During 2018, migrants from Venezuela constituted $96 \%$ of imported malaria cases along the Ecuador-Peru border. Plasmodium vivax predominated (96\%). Autochthonous malaria cases emerged in areas previously malaria-free. Heightened malaria control and a response to this humanitarian crisis are imperative.

$\mathrm{M}$ alaria is a vectorborne parasitic infection caused by Plasmodium spp. and transmitted by Anopheles mosquitoes, characterized by fever and hemolysis with chronic and fatal potential (1). Despite substantial strides toward elimination in the Americas, malaria remains a major concern; $\approx 975,700$ cases occurred and 138 million persons were at risk in 2017 (2). Most malaria cases in South America occur in the Amazon region, and $P$. vivax is more common than P. falciparum (3).

$P$. vivax and $P$. falciparum malaria were historically endemic to the Ecuador-Peru coastal border region. During 1990-2012, a total of 62,000 malaria cases were reported from El Oro Province, Ecuador, and 85,605 from Tumbes Region, Peru (4). Through vector control and active case surveillance and response, malaria was eliminated from El Oro Province in 2011 and Tumbes Region in 2012 (4). However, malaria cases elsewhere in Ecuador increased from 378 in 2013 (5) to 1,279 in 2017 (6). Peru and other countries in the region also reported increased malaria in 2017, indicating a major risk for reintroduction to elimination areas (2). In 2017, Venezuela alone accounted for more than half of all malaria cases in the Americas (2).

The public health sector in Venezuela is struggling with infectious disease epidemics, including malaria (7), despite a historically successful malaria control program (3). The worsening social and economic crisis has led to large-scale migration from and within Venezuela. The shortage of antimalarial drugs and lax in-country control efforts have exacerbated the situation, affecting countries throughout South America (8). Many people from Venezuela are migrating through Colombia and Ecuador to reach Peru and the southern cone of South America, stopping at various locations along the way (Figure). We report a series of imported malaria cases in migrants from Venezuela and the first autochthonous cases of malaria in the EcuadorPeru border region since local elimination. 


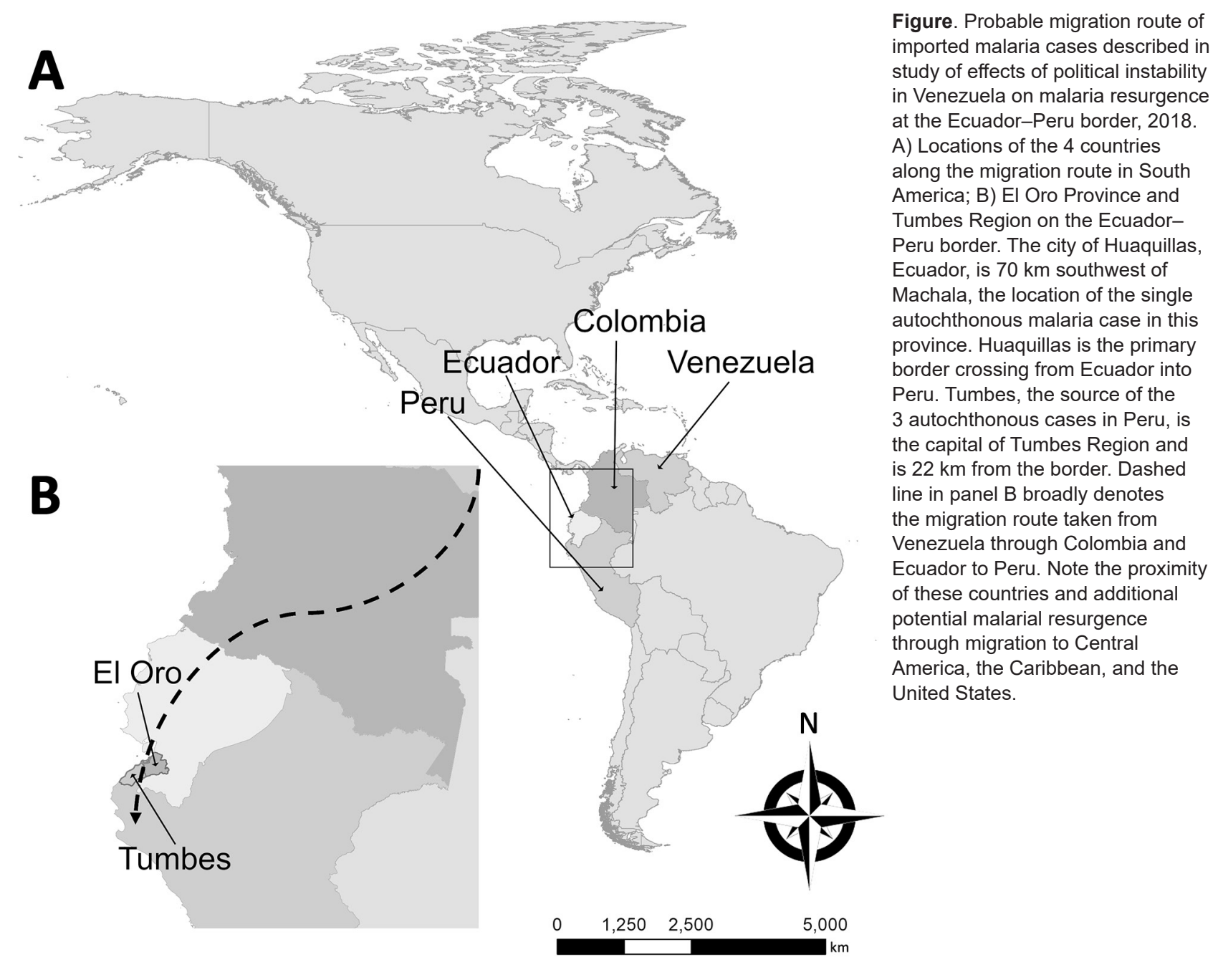

During February-November 2018, seven malaria cases (6 P. vivax, 1 P. falciparum) were detected in adults in El Oro Province and reported to the Ecuadorian Ministry of Health (Appendix, https://wwwnc.cdc.gov/EID/ article/25/4/18-1355-App1.pdf). Five cases occurred in recent migrants from Venezuela, and 1 was imported from Peru. The most recent case (no. 7), reported in November 2018, was autochthonous. Plasmodium spp. infection was confirmed at the national reference laboratory in Guayaquil, Ecuador. Active surveillance within $1 \mathrm{~km}$ of each case-patient's residence revealed no acute cases, and collateral thick blood smears were negative. Entomologic teams documented Aedes aegypti and Culex spp. mosquitoes in the homes but no Anopheles mosquitoes. The residences all had basic infrastructure and no history of malaria since local elimination in 2011.

During May-October 2018, a total of 20 P. vivax malaria cases were detected in adults in Tumbes Region and reported to the Peruvian Ministry of Health (Appendix). Seventeen cases occurred in Venezuelan migrants now living in the province, and 3 were autochthonous cases in persons residing in Tumbes. An epidemiologic investigation revealed that the autochthonous case-patients had no history of travel outside of Tumbes Region.

We cannot definitively state whether the migrants from Venezuela were exposed to malaria in Venezuela or during transit. Regardless, this population represents a highly vulnerable group with complex treatment issues. Malaria should be considered in the differential diagnosis for febrile patients from Venezuela and for local populations in nearby parts of South America. The transience of the migrant population presents treatment follow-up issues. The incubation period for P. vivax malaria is $12-18$ days and, for P. falciparum malaria, 9-14 days. Case-patients (Appendix) often exhibited inadequately or untreated malaria. Imported cases are the likely source of the locally transmitted cases in Tumbes Region and El Oro Province because the primary mosquito vectors (An. albimanus and An. punctimacula) remain abundant in this area (9). Another concern is relapse of dormant $P$. vivax hypnozoites, which can occur up to 
several years after initial infection (1). Issues with primaquine (i.e., CYP2D6-poor metabolizers or hemolysis risk in patients with glucose-6-phosphate dehydrogenase deficiency) complicate treatment of dormant hypnozoites that cause relapse (1). A new treatment, tafenoquine, which still causes hemolysis in glucose-6-phosphate dehydrogenase deficiency, was recently approved in the United States as a single dose for prevention of $P$. vivax malaria relapse (10), although this medication might not reach at-risk groups in South America. Ecuador and Peru currently follow the Pan American Health Organization guidelines regarding primaquine use (https://www.paho.org/hq/dmdocuments/2011/ TreatmentGuidelines-2nd-ed-2010-eng.pdf).

Local ministries of health responded quickly to these cases and implemented case surveillance. However, reductions in resources after elimination of local malaria transmission in 2011-2012 severely limited malaria control efforts in Ecuador and Peru. Imported cases of malaria at the Ecuador-Peru border region pose a serious threat of continued resurgence in local transmission. We urge international solutions for Venezuela's humanitarian crisis and augmentation of infectious disease surveillance and control along migration routes and in surrounding regions.

\section{About the Author}

Dr. Jaramillo-Ochoa is an epidemiologist working for the Ministry of Health for the Health District of the city of Machala, El Oro Province, Ecuador. His primary research interests include the epidemiology of vectorborne diseases and monitoring and evaluating vector-control interventions.

\section{References}

1. Ashley EA, Pyae Phyo A, Woodrow CJ. Malaria. Lancet. 2018; 391:1608-21. http://dx.doi.org/10.1016/S0140-6736(18)30324-6

2. World Health Organization. World malaria report 2018. Geneva: The Organization; 2018.

3. Recht J, Siqueira AM, Monteiro WM, Herrera SM, Herrera S, Lacerda MVG. Malaria in Brazil, Colombia, Peru and Venezuela: current challenges in malaria control and elimination. Malar J. 2017;16:273. http://dx.doi.org/10.1186/s12936-017-1925-6

4. Krisher LK, Krisher J, Ambuludi M, Arichabala A, Beltrán-Ayala E, Navarrete P, et al. Successful malaria elimination in the Ecuador-Peru border region: epidemiology and lessons learned. Malar J. 2016;15:573. http://dx.doi.org/10.1186/ s12936-016-1630-x

5. World Health Organization. World malaria report 2014: Ecuador. Geneva: The Organization; 2014.

6. Ministerio de Salud Pública de Ecuador. Gaceta Vectorial SE 1-52, 2017. 2018 Jan 3 [cited 2018 Apr 15]. https://www.salud.gob.ec/ wp-content/uploads/2017/07/Gaceta-Vectorial-SE52.pdf

7. Hotez PJ, Basáñez MG, Acosta-Serrano A, Grillet ME. Venezuela and its rising vector-borne neglected diseases. PLoS Negl Trop Dis. 2017;11:e005423. http://dx.doi.org/10.1371/journal.pntd.0005423

8. Grillet ME, Villegas L, Oletta JF, Tami A, Conn JE. Malaria in Venezuela requires response. Science. 2018;359:528.

9. Ryan SJ, Lippi CA, Boersch-Supan PH, Heydari N, Silva M, Adrian J, et al. Quantifying seasonal and diel variation in
Anopheline and Culex human biting rates in southern Ecuador. Malar J. 2017;16:479. http://dx.doi.org/10.1186/s12936-017-2121-4 10. Frampton JE. Tafenoquine: first global approval. Drugs. 2018;78:1517-23. http://dx.doi.org/10.1007/s40265-018-0979-2

Address for correspondence: Anna M. Stewart-Ibarra, Institute for Global Health \& Translational Science, State University of New York Upstate Medical University, 505 Irving Ave, Syracuse, NY 13210, USA; email: stewarta@upstate.edu

\section{Rickettsia parkeri and Candidatus Rickettsia andeanae in Ticks of the Amblyomma maculatum Group, Mexico}

\author{
Jesús Delgado-de la Mora, ${ }^{1}$ \\ Sokani Sánchez-Montes, ${ }^{1}$ \\ Jesús D. Licona-Enríquez, ${ }^{1}$ \\ David Delgado-de la Mora, ${ }^{1}$ \\ Christopher D. Paddock, Lorenza Beati, \\ Pablo Colunga-Salas, Carmen Guzmán-Cornejo, \\ Maria L. Zambrano, Sandor E. Karpathy, \\ Andrés M. López-Pérez, \\ Gerardo Álvarez-Hernández
}

Author affiliations: Instituto Nacional de Ciencias Médicas y Nutrición Salvador Zubirán, Mexico City, Mexico (J. Delgado-de la Mora); Universidad Nacional Autónoma de México, Mexico City (S. Sánchez-Montes, P. Colunga-Salas, C. Guzmán-Cornejo, A.M. López-Pérez); Centro Médico Nacional Siglo XXI, Mexico City (J.D. Licona-Enríquez); Instituto Tecnológico de Sonora, Sonora, Mexico (D. Delgado-de la Mora); Centers for Disease Control and Prevention, Atlanta, Georgia, USA (C.D. Paddock, M.L. Zambrano, S.E. Karpathy); Georgia Southern University, Statesboro, Georgia, USA (L. Beati); Universidad de Sonora, Sonora (G. Álvarez-Hernández)

DOI: https://doi.org/10.3201/eid2504.181507

We report Rickettsia parkeri and Candidatus Rickettsia andeanae in ticks of the Amblyomma maculatum group collected from dogs in Sonora, Mexico. Molecular characterization of these bacteria was accomplished by DNA amplification and sequence analysis of portions of the rickettsial genes gltA, htrA, ompA, and ompB.

${ }^{1}$ These authors contributed equally to this article. 